\title{
СУЧАСНІ АСПЕКТИ УПРАВЛІННЯ ЯКІСТЮ ПРОДУКЦІї ТА ПОСЛУГ ПІДПРИЕМСТВ ГОТЕЛЬНО-РЕСТОРАННОГО ГОСПОДАРСТВА
}

\section{MODERN ASPECTS OF QUALITY MANAGEMENT OF PRODUCTS AND SERVICES OF HOTEL AND RESTAURANT ENTERPRISES}

\author{
Язіна Вікторія Анатоліївна \\ кандидат економічних наук, доцент, \\ Університет митної справи та фрінансів \\ ORCID: https://orcid.org/0000-0002-8695-3456 \\ Кучер Маргарита Миколаївна \\ кандидат економічних наук, доцент, \\ Університет митної справи та фрінансів \\ ORCID: https://orcid.org/0000-0002-3868-5311 \\ Сабіров Олександр Володимирович \\ кандидат технічних наук, доцент, \\ Університет митної справи та фрінансів \\ ORCID: https://orcid.org/0000-0001-9436-0477 \\ Yazina Viktoriia, Kucher Marharyta, Sabirov Oleksandr \\ University of Customs and Finance
}

\begin{abstract}
Стаття присвячена засадам успішного фрунцціонування та розвитку підприємств готельно-ресторанного господарства за умов успішного управління якістю продукції та послуг підприємств готельно-ресторанного господарства. Проаналізовано, що якість продукції та послуг підприємств готельно-ресторанного господарства це головний критерій успіху ведення бізнесу. Аргументовано, що управління якістю продукції та послуг підприємств готельно-ресторанного господарства - один із основних інструментів менеджменту та маркетингу та потребує ґрунтовного дослідження. Висвітлено сучасний стан якості продукції та послуг підприємств готельно-ресторанного господарства. Наведено характеристику особливостей сучасних систем управління якістю продукції та послуг підприємств готельно-ресторанного господарства. Розглянуто актуальність створення та розробки актуальних напрямів управління якістю продукції та послуг підприємств готельно-ресторанного господарства на вітчизняному рівні та обґрунтовано необхідність їх застосування на практиці як багатоелементної системи, що має позитивний вплив на функціонування готельно-ресторанного господарства.

Ключові слова: підприємства готельно-ресторанного господарства, продукція, послуги, управління, якість.
\end{abstract}

Статья посвящена принципам успешного функционирования и развития предприятий гостинично-ресторанного хозяйства в условиях успешного управления качеством продукции и услуг предприятий гостиничноресторанного хозяйства. Проанализировано, что качество продукции и услуг предприятий гостинично-ресторанного хозяйства - это главный критерий успеха ведения бизнеса. Аргументировано, что управление качеством продукции и услуг предприятий гостинично-ресторанного хозяйства - один из основных инструментов менеджмента и маркетинга и требует основательного исследования. Освещено современное состояние качества продукции и услуг предприятий гостинично-ресторанного хозяйства. Приведена характеристика особенностей современных систем управления качеством продукции и услуг предприятий гостинично-ресторанного хозяйства. Рассмотрена актуальность создания и разработки актуальных направлений управления качеством продукции и услуг предприятий гостинично-ресторанного хозяйства на отечественном уровне и обоснована необходимость их применения на практике как многоэлементной системы, что оказывает положительное влияние на функционирование гостинично-ресторанного хозяйства.

Ключевые слова: качество, предприятия гостинично-ресторанного хозяйства, продукция, услуги, управление. 
The article is devoted to the principles of successful functioning and development of hotel and restaurant enterprises under the conditions of successful quality management of products and services of hotel and restaurant enterprises. It is analyzed that the quality of products and services of hotel and restaurant enterprises is the main criterion for business success. It is argued that quality management of products and services of hotel and restaurant enterprises is one of the main tools of management and marketing and requires thorough research. The current state of quality of products and services of hotel and restaurant enterprises is highlighted. The characteristic of features of modern systems of management of quality of production and services of the enterprises of hotel and restaurant economy is resulted. The urgency of creating and developing current areas of quality management of products and services of hotel and restaurant industry at the national level is considered and the need for their application in practice as a multi-element system that has a positive impact on the functioning of hotel and restaurant industry. A special role belongs to the organization of quality management in the hotel and restaurant industry, the creation and implementation of quality management systems, aspects of economic quality management in enterprises, modern tools and technologies for quality assurance in the hotel and restaurant industry. Quality management is the most important element in ensuring the competitiveness of products and services of hotels and restaurants. Production and provision of high quality services helps to reduce production costs and their provision, saving social work, better use of raw materials, greater production efficiency. Ensuring and improving the quality of hotel and restaurant products and services is a complex issue that includes technical, economic, social, political and legal aspects. Particular attention is paid to quality management systems of products and services of hotels and restaurants based on current trends and international management concepts that can significantly regulate quality based on laws and regulations in the field of consumer protection.

Keywords: hotel and restaurant enterprises, management, quality, products, services.

Постановка проблеми. Спалах коронавірусної хвороби (COVID-19) виступив масовим стримуванням на ринку підприємств готельно-ресторанного господарства у 2020-2021 роках, оскільки майже всі країни глобально ввели обмеження на внутрішні та міжнародні поїздки. Протягом 2020-2021 років вплив локальних заборон та туристичних обмежень змусило велику кількість підприємств готельно-ресторанного господарства тимчасово закритись або працювати на невелику частку від їх наявної потужності, що достатньо негативно вплинуло на розвиток індустрії гостинності.

На разі вітчизняні готельєри та ресторатори намагаються відродити та вивести свій бізнес хоча б «у нуль», що особливо важливо у сучасних умовах, адже саме під час пандемії «COVID-19» особливо важко втримати увагу та пріоритет клієнта на підприємствах готельно-ресторанного господарства. Тому важливо використовувати особливі підходи до управління якістю продукції та послуг на підприємствах готельно-ресторанного господарства та слідкувати за сучасними тенденціями індустрії гостинності.

Аналіз останніх наукових досліджень і публікацій. Вагомий науковий внесок в опрацювання питань готельно-ресторанного господарства зробили такі вітчизняні та зарубіжні дослідники: У.Ф. Аренс, Д. Бернет, К.Л. Бове, С. Броадбент, І.Л. Вікентьєв, А.В. Войчак, Н.А. Гасаненко, А. Дейян. Проблемами готельно-ресторанного господарства займалися і займаються такі вчені як Т.І. Ткаченко, М.В. Соколова, І.Г. Смірнов, В.Б. Сапру- нов, Д.І. Воротіна, О.В. Арефф'єва, В.О. Ткач, С.О. Камушков, Г.Я. Круль, П.Р. Пуцентейло, М.П. Мальська та інші.

Виділення невирішених раніше частин загальної проблеми. На сьогодні немає науково обґрунтованої теорії успішного управління якістю продукції та послуг підприємств готельноресторанного господарства. Впровадження успішного інструментарію управління якістю надає підприємствам готельно-ресторанного господарства не тільки конкурентну перевагу у складних економічних і ринкових умовах.

Формулювання цілей статті - визначити сучасний стан розвитку підприємств готельно-ресторанного господарства. Розглянути та проаналізувати основні підходи управління якістю продукції та послуг підприємств готельно-ресторанного господарства. Визначити сучасні ефективні тенденції управління якістю підприємствами готельно-ресторанного господарства.

Виклад основного матеріалу. Згідно 3 дослідженнями консалтингової компанії Deloitte перспективними напрямами розвитку світової індустрії гостинності будуть наступні:

1. Розширення пропозиції на перспективних зростаючих ринках та вдосконалення цифрових і соціальних стратегій.

2. Підвищення рівня безпеки (прийняття та/або вдосконалення перспективних рішень в галузі безпеки щодо біометрії, електронних віз, передової кіберрозвідки і аналітики).

3. Скорочення витрат, в тому числі вдосконалення методів управління доходами, оптимізація ланцюжка поставок і підвищення коефріцієнта завантаження авіакомпаній. 
4. Залучення до готельного сектору перспективних фрахівців, підвищення рівня утримання співробітників і пошук шляхів використання нових технологій для розширення можливостей більш інтелектуальної робочої сили [4].

5. Впровадження персоналізованого підходу в обслуговуванні клієнтів. Необхідно впроваджувати у діяльність готельних мереж аналіз великих даних для розуміння своїх клієнтів, вимірювання та моніторинг мінливих очікувань клієнтів, а також створення автентичного досвіду.

6. Діджиталізація готельних послуг. Вона охоплює інвестиції в технології та способи реструктуризації організацій для адаптації і зміни корпоративної культури 3 метою впровадження інновацій, що використовують технології [1].

Спалах коронавірусу та подальші заходи безпеки мали значний вплив на гостинність протягом 2020 року, що продовжуються і у 2021 році. Деякі реакції на цю надзвичайну ситуацію, спроби залучити меценатів до закладів харчування та розміщення та запевнити відпочиваючих, що насолоджуватися перебуванням у готелях та готелях справді безпечно, пришвидшили існуючі тенденції індустрії гостинності та спричинили тривалі зміни. В останні роки з'явилося декілька нових напрямів розвитку у світовій індустрії гостинності (рис. 1).

Визначимо сучасні тенденції управління якістю підприємств готельно-ресторанного господарства. До найпріоритетніших можна віднести наступні:

1. Безпека: інфрормаційна, фрінансова, пожежна, кібербезпека, дотримання санітарних норм тощо. Необхідно забезпечувати не тільки безпеку клієнтів, але й персоналу.
2. Використання інформаційно-комунікаційних технологій під час обслуговування клієнтів. Це охоплює все більшу цисрровізацію послуг, що надаються на підприємствах готельно-ресторанного господарства. Наприклад, завдяки Інтернету здійснюється доступ до сервісів, голосове управління, готельний номер закривається та відкривається за допомогою ключа у смартфоні, контроль температури в номері також здійснюється через смарторон. Все це обумовлює більш персоналізоване обслуговування гостей, що $€$ великою перевагою в роботі підприємств готельно-ресторанного господарства. Окрім того, наявність послуги безконтактної і мобільної реєстрації дозволяє гостям минути стійку реєстрації і пройти прямо в готельний номер або до столика у ресторані за допомогою безконтактної реєстрації, яка миттєво видає цифровий ключ від номера на смартфрон гостя або автоматизовано показує ваш заброньований столик у ресторані [5].

3. Екологічність. Сучасні гості женуться за тими підприємствами, які впровадили екологічні практики в усі аспекти своєї діяльності. Це охоплює фрізичні зміни в будівлях готелів та ресторанів, такі як використання сонячних батарей, душових насадок з повільною витратою води, відмова від пластику, економія електроенергії шляхом встановлення датчиків руху, які відключають живлення, якщо протягом певного періоду часу не було виявлено жодного руху, знаходження більш екологічних варіантів утилізації відходів, пропонування меню в ресторанах із великою кількістю вегетаріанських і веганських страв.

4. Пропонування альтернативних варіантів харчування та розміщення. Це пов'язано,

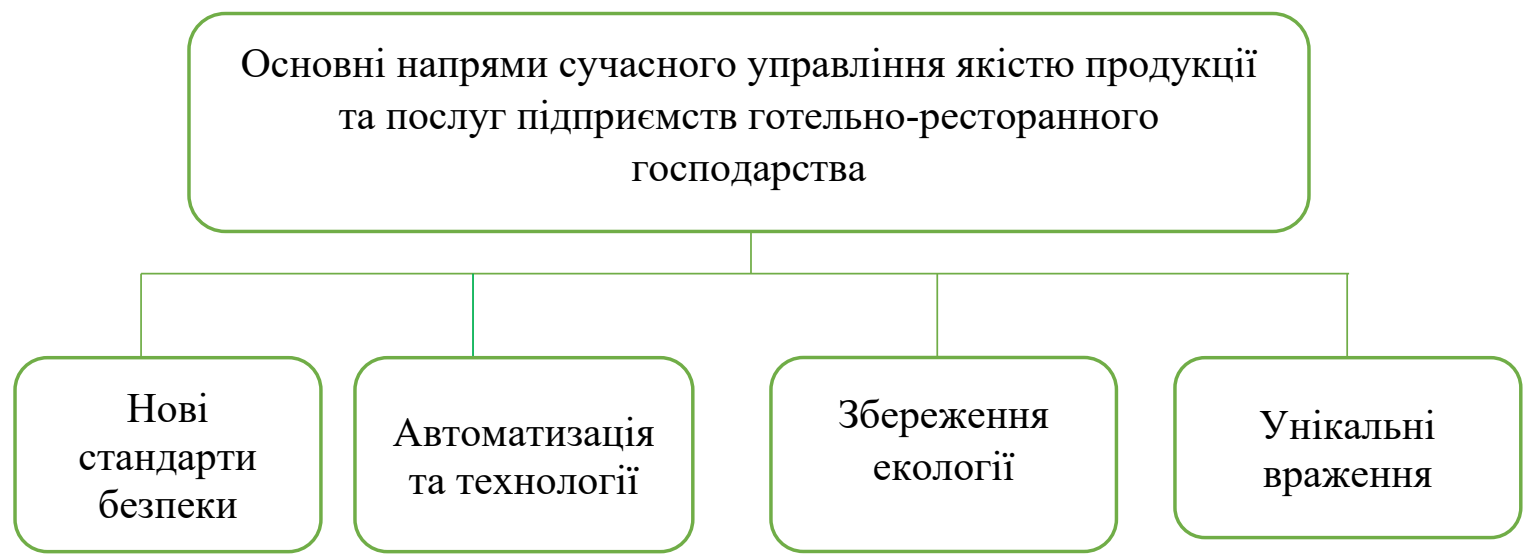

Рис. 1. Основні напрями сучасного управління якістю продукції та послуг підприємств готельно-ресторанного господарства

Джерело: складено автором на основі [3] 
наприклад, із віддаленим режимом роботи, коли робітники, що працюють за таким режимом, шукають коворкінг-простів не тільки зі швидким WiFi i робочим місцем, але й з можливостями для спілкування та налагодження контактів. Окрім того, актуальним $€$ впровадження технологій віртуальних зустрічей і засобів комунікацій в режимі реального часу.

5. Пропонування не тільки хороших умов харчування та проживання, а й нових вражень. Наприклад, це може охоплювати розширення спектру готельно-ресторанних послуг, фрормування унікальних продуктів та послуг із використанням індивідуального підходу: гастрономічні подорожі; експериментальні подорожі; музикальні подорожі; кулінарні майстер-класи; подорожі для оздоровлення; медичний туризм тощо.

6. Глобалізація і централізація управління підприємствами у готельно-ресторанному господарстві. Це охоплює необхідність врахування культурних і мовних очікувань іноземних клієнтів, надання креативних та інноваційних пропозицій, щоб здивувати своїх гостей.

7. Зростання, розширення геограсрії та розвиток міжнародних готельно-ресторанних мереж.

8. Інтеграція готельно-ресторанних мереж із іншими підприємствами індустрії туризму. Це означає розширення участі інших підприємств у готельно-ресторанному бізнесі за рахунок концентрації та переміщення капіталу, як з туризму, так і з інших галузей.

9. Гібридизація готельно-ресторанного продукту [6].

10. Надання більше пропозицій для ділових туристів.

11. Впровадження робототехніки. Роботи можуть виконувати фрункції адміністратора, служби доставки, консьєржа, носія багажу, охоронця, використовуючи фрункції розпізнавання мови та інші для відповіді на запити клієнтів.

12. Постійний вплив економічної та політичної ситуації в світі на туризм та готельноресторанне господарство [2].

Всі зазначені тенденції обумовлені необхідністю інвестицій, однак необхідно пам'ятати, що впровадження нових послуг і практична реалізація нових ідей - це завжди ризик, тому вони повинні бути добре прораховані і продумані.

Висновки з проведеного дослідження. Готелі, ресторани та інші заклади гостинності рухаються до нових варіантів здорової їжі та напоїв. Від вегетаріанських та безглютенових страв до органічних продуктів, багато гостей шукають широкий вибір продуктів харчування та напоїв, які відповідають їх особистому стилю життя. Хоча це не обов'язково очіку- ється пересічним клієнтом, пропонування особливої їжі та напоїв $є$ ключовим маркетинговим пунктом для закладів гостинності.

Тим часом еволюція на суспільному рівні, наслідок частково змінених цінностей після найгострішої фрази пандемії та підвищення обізнаності споживачів про заходи безпеки, встановила нові еталони для підприємств гостинності. Певна категорія людей залишається вдома з екологічних або бюджетних міркувань.

Безконтактні технології, додатки стають все більш важливими в тому, як готельєри управляють послугами, які вони надають своїм клієнтам, і тепер вони можуть контролювати багато аспектів гостьового циклу та досвіду. Тенденція до цифррових та безконтактних послуг набрала нових темпів у 2020-2021 роках. Традиційно послуги, спрямовані на клієнтів, отримують пересрорматування, завдяки більш широкому використанню технологічних можливостей, таких як мобільна реєстрація, безконтактні платежі, голосовий контроль та біометрія.

Споживачі, які звикли розблоковувати свої смарторони та ноутбуки за допомогою розпізнавання обличчя та відбитків пальців, незабаром очікують такої ж зручності при доступі до своїх готельних номерів. На жаль для установ, які бажають їх прийняти, ці оновлення можуть бути дорогими для встановлення та обслуговування.

Автоматизація та технології - широка категорія, що говорить про технологічний розвиток, який, як виявляється, скорочує час очікування, делегує роботам важкі завдання та використовує великі дані для оптимізації процесів, наприклад. Чат-боти, що працюють на основі штучного інтелекту, виявились перевагою в обслуговуванні клієнтів як під час процесу бронювання, так і у відповіді на періодичні запитання щодо захисних заходів, які стосуються COVID-19.

У світлі непередбачених та нерівномірних впливів на попит, спричинених COVID-19, оцінка стратегічних рішень щодо активів гостинності вимагає повного переосмислення прогнозування результатів діяльності. Незалежно від оцінки придбання, розподілу капітальних витрат, переговорів з позикодавцями, управління активами або оцінки та прийняття рішень щодо найкращого використання, пандемія COVID-19 змусила індустрію гостинності прийняти новий план управління якістю продукції та послуг підприємств готельноресторанного господарства, що будується на новітніх маркетингових технологіях. 


\section{СПИСОК ВИКОРИСТАНИХ ДЖЕРЕЛ:}

1. Артемова О.М., Козлова В.А. Основи гостинності та туризму. URL: http://infotour.in.ua/artemova8-2.htm\#

2. Інформаційний портал у ссрері гостинності «Hospitality ON». URL: http://mkg-group.com/fileadmin/ Emailings

3. Гоблик-Маркович Н.М. Напрями формування сучасної маркетингової стратегії розвитку підприємств готельно-ресторанного бізнесу. Перспективи розвитку готельно-ресторанної індустрії України: теорія, практика, інновації розвитку : тези доповідей Всеукраїнської науково-практичної конфреренції. Мукачево : РВВ МДУ, 2018. 113 с.

4. Миронова М.І., Миронов Ю.Б. Показники ефрективності діяльності підприємств індустрії гостинності. Сучасні технології менеджменту, інфрормаційне, фрінансове та облікове забезпечення розвитку економіки в умовах євроінтеграції : Матеріали Всеукраїнської науково-практичної конференції. Черкаси : Східноєвропейський університет економіки і менеджменту, 2020. С. 517-520.

5. Пуцентейло П.Р. Економіка і організація туристично-готельного підприємництва. URL: https://tourlib.net/ books_ukr/pucentejlo51.htm

6. «Revfine» - платсорма знань з індустрії гостинності та туризму. URL: https://www.revfine.com/hospitalityindustry

\section{REFERENCES:}

1. Artemova O.M., Kozlova V.A. Osnovi gostinnosti ta turizmu [Basics of hospitality and tourism]. Retrieved from: http://infotour.in.ua/artemova8-2.htm\#

2. Informacijnij portal u sferi gostinnosti «Hospitality ON» [Hospitality ON information portal]. Retrieved from: http://mkg-group.com/fileadmin/Emailings

3. Goblyk-Markovych N.M. (2018) Napryamy formuvannya suchasnoyi marketyngovoyi strategiyi rozvytku pidpryyemstv gotelno-restorannogo biznesu [Directions of formation of modern marketing strategy of development of the enterprises of hotel and restaurant business]. Mukachevo: RVV MDU, p. 113. (in Ukrainian)

4. Mironova M.I., Mironov Y.B. (2020) Pokazniki efektivnosti diyal'nosti pidpriemstv industrii gostinnosti [Indicators of efficiency of enterprises of the hospitality industry]. Cherkasy: Eastern European University of Economics and Management, pp. 517-520. (in Ukrainian)

5. Ekonomika i organizaciya turistichno-gotelnogo pidpriemnictva [Economics and organization of tourism and hotel business]. Retrieved from: https://tourlib.net/books_ukr/pucentejlo51.htm

6. «Revfine» - platforma znanz industriï gostinnosti ta turizmu [Revfine is a knowledge platform for the hospitality and tourism industry]. Retrieved from: https://www.revfine.com/hospitality-industry 